\title{
HEALTH SELF-EVALUATION OF ELDERLY PERSONS WITH VISUAL IMPAIRMENTS IN RELATION TO GENDER AND STATE OF HEALTH
}

\author{
Amela Teskeredžić ${ }^{1}$ \\ Dženana Radžo Alibegović \\ Hurma Begić
}

Original scientific paper

DOI:10.21554/hrr.091704

University of Tuzla, Faculty of Education and Rehabilitation, Bosnia and Herzegovina

Received: 08.06.2017

Accepted: 24.08.2017

\begin{abstract}
Health self-evaluation, as a subjective measure, is related to person's well-being because it encapsulates physical and emotional health evaluation. It has been concluded that subjective health is, for most of people, number one trait of quality of living that is connected to health. Individual is to decide which aspects of objective situation are important for their satisfaction in life. In other words, way in which a person will perceive and react to an objective situation depends on their personal traits. Aim of this research was to examine the differences in relation to gender and health state of visually impaired older persons of that live in institutional accommodation, by self-evaluation. Respondents sample was comprised of 40 visually impaired older persons, both genders (13 male and 27 female) that live in nursing home "Dom penzionera" in Tuzla. Research has been conducted by interview, using questionnaire "Quality of life of adult persons with motoric disabilities in territory of Vojvodina" (Susnjevic, 2015). Because of the structure of questions in questionnaire, it was possible to apply it on visually impaired persons as well. Data acquired had been processed with descriptive statistics, hi-squre and $t$-test, in order to determine if there were differences in relation to gender and selfevaluation of physical and social functioning. Results of the research have shown that although means have proven that there are differences in acquired results between respondents of male and female gender, results of t-test have shown that those differences are not statistically significant. Presence of any kind of damage, and visual impairment as well can influence person's psychological and physical integrity.
\end{abstract}

Keywords: health self-evaluation, visual impairment, elderly

\section{INTRODUCTION}

According to newer aging studies, importance of subjective health is more and more articulated. Individuals have information on their health that we cannot obtain from any other source, regardless how profound and detailed it is. Furthermore, they analyze that data and make conclusions of their meaning in ways that are completely unfamiliar (Idler, 1999). Despite large number of definitions and disagreements around the term "Quality of Life", many authors think that it is about combination of subjective and objective variables (Vuletic \& Mujkic, 2002: Fakhoury \& Prieve, 2002, according to Coric \& Ljubotina, 2013). Demographic variables such as gender, age, degree of education, marital status and socio-economic status can affect some differences in objective life conditions and ways in which individual assess and experiences quality of one's life (Lucev \& Tadinac, 2008).

\footnotetext{
${ }^{1}$ Correspodence to:

Amela Teskeredžić, Faculty of Education and Rehabilitation, University of Tuzla

Univerzitetska 1, 75000 Tuzla, Bosnia and Herzegovina

Phone: +38761 195865

E-mail: amela.teskeredzic@untz.
} 
Subjective health or self-evaluation of healthis influenced by numerous biological and non-biological factors: personality, motivation, socio-economic status, availability of health-care, social support network, personal and cultural beliefs and approach to one's health. Health self-evaluation as a subjective measure is related to person's well-being because it covers evaluation of physical and emotional health. Subjective health, for most persons, is number one trait of quality of life, related to health. Therefore it is often considered as an indicator of quality of life related to health and functional ability (Bowling, 1991; Bosworth et al., 1999). Measures of functional abilities are usually based on respondents' self-evaluation and therefore are affected by same influences as other states of respondents conducting self-evaluation. Individual determines for himself which aspects of objective situation are important for their satisfaction in life. In other words, way in which a person will perceive and react to an objective situation depends on their personal traits. In a very unfavorable situation we will have individuals that are relatively or very satisfied with their lives. People with serious health problems can be satisfied with their lives, even with the health state they are in, if their expectations are adjusted to the situation at hand. On the other hand, in objective favorable situations we will have individuals that are relatively unsatisfied with their health and/or life in general (Lucev \& Tadinac, 2008). All this implies the fact that self-evaluation, subjective feeling of quality of life and objective life conditions are not linearly correlated and correlation is stronger as objective life conditions are worse ( Vuletic \& Mujkic, 2002a). According to some authors, quality of life self-evaluation is affected by the way in which person defines their life situation comparing it to their situation in some other time and with situations of other people and no harmony between person's aspirations and reality in some point in time (Fakhoury \& Priebe, 2002, according to Coric \& Ljubotina, 2013). As an important factor of subjective satisfaction is possibility of alignment of reality and person's aspirations in way of life (Berger \& Motl, 2001, according to Lorger, 2011). Vuletic and Mujkic (2002b) point out that every person has different experience of a situation in which they live in, has different aspirations and expectations, in other words they have different value system and therefore different evaluation of their own life.

Eyesight is along hearing and touch main sensor function that connects people with one another and their environment (Wes et al., 1997). Therefore it is not hard to conclude that eyesight quality is main part of quality of life (Tsai et al., 2004). Reduced sharpness of eyesight is most commonly connected to reduced quality of life. Many authors claim that refraction errors that are not dealt with, glaucoma, cataract, diabetic retinopathy, macular degeneration are all connected to reduced quality of life (Broman et al., 2002; Berman \& Brodaty, 2006, according to Pinquart \& Pfeiffer, 2011; Navarro Esteban et al., 2008; Fenwick et al., 2012). Franke et al., (2005), according to Maca et al., (2013) claim that uveitis has relation to reduced quality of life. Regardless of time in which visual impairment started, worsening in quality of life is growing as degree of visual impairment is growing with all pathological conditions (Navarro Esteban et al., 2008). Binocular visual impairment is related to twice as risk in functioning ability reduction (West et al., 1997), where in research conducted by Vu et al., (2005), according to Nyman et al., (2008) those persons stated up to four times more that they "do not feel life at its fullest". In other words, persons with visual impairments on one eye are less affected in terms of quality of life then persons with visual impairments on both eyes, which are logical conclusions (Sekeroglu et al., 2012). Aim of this research was to examine differences in selfevaluation of physical and social functioning capabilities, feeling about life and health of elderly people with visual impairments that live in in institutional accommodation in relation to gender.

\section{WORK METHODS}

Sample of respondents was consisted of 40 visually impaired elderly persons, both genders (13 male and 27 female) living in nursing home "Dom Penzionera" in Tuzla. Research has been conducted via interview in period between September and December 2016, with questionnaire "Quality of life of adult persons with motoric disabilities in territory of Vojvodina" (Susnjevic, 2015). Because of the structure of questions in questionnaire, it was possible to apply it on visually impaired persons as well. Questionnaire had four examination areas: physical functioning (9 variables), social functioning (3 variables), feeling about life scale (10 variables), and health state self-evaluation (1 variable), which is in total 23 variables and the rest of the questions are related to general information about respondents. Data acquired are processed with descriptive statistics, hi-square and t-tests in order to examine differences in relation to gender and self-evaluation of social and physical functioning. 


\section{RESULTS}

Measurements of tendency and dispersion in relation to applied scales of physical and social evaluation and scales of feelings about life are shown in Table 1. Every scale is consisted of array of questions. In order to get total result transformation has been applied to calculate sum of questions in individual scales and get total result, which is measurement scale of interval type. Scale of physical functioning is consisted of 8 variables and results are in range between 8 and 26 where lower results indicate better physical functioning. Social functioning scale is consisted of 3 variables and results range between 3 and 12. Scale of feeling about life is consisted of 10 variables and total results range between 10 and 50 . Health self-evaluation scale is consisted of one question where results range between 1 and 5. Acquired results show that in relation to variable "Physical functioning" mean is $10.45 \pm 3.50$, median 9, modus 8 , while minimal and maximal results range between 8 and 24. Mean of variable „Social functioning“ is $7.25 \pm 2.32$, median 7 , modus 7 , minimal and maximal results range between 3 and 11. Mean of variable „Scale of feelings about life“ is $31.98 \pm 22.79$, median 32 , modus 13, minimal and maximal results range between 26 and 38 (Table 1).

Table 1. Measurements of central tendency and measurements of dispersion

\begin{tabular}{lcccccccc}
\hline Variables & $\mathbf{N}$ & $\mathbf{M}$ & SE & Median & Modus & SD & Min & Max \\
\hline Physical functioning & 40 & 10,45 & 0,55 & 9,00 & 8,00 & 3,50 & 8,00 & 24,00 \\
\cline { 2 - 8 } Social functioning & 40 & 7,25 & 0,37 & 7,00 & 7,00 & 2,32 & 3,00 & 11,00 \\
\cline { 2 - 8 } Feelings about life scale & 40 & 31,98 & 0,44 & 32,00 & 31,00 & 2,79 & 26,00 & 38,00 \\
\hline
\end{tabular}

Respondents' responses distribution in relation to health self-evaluation is shown in Graph 1.

Largest number of respondents evaluates their health as good (37.5\%) and average (35\%). Respondents that evaluated their health was $7.5 \%$, while $2.5 \%$ and $17.5 \%$ evaluate their health as very bad and bad.

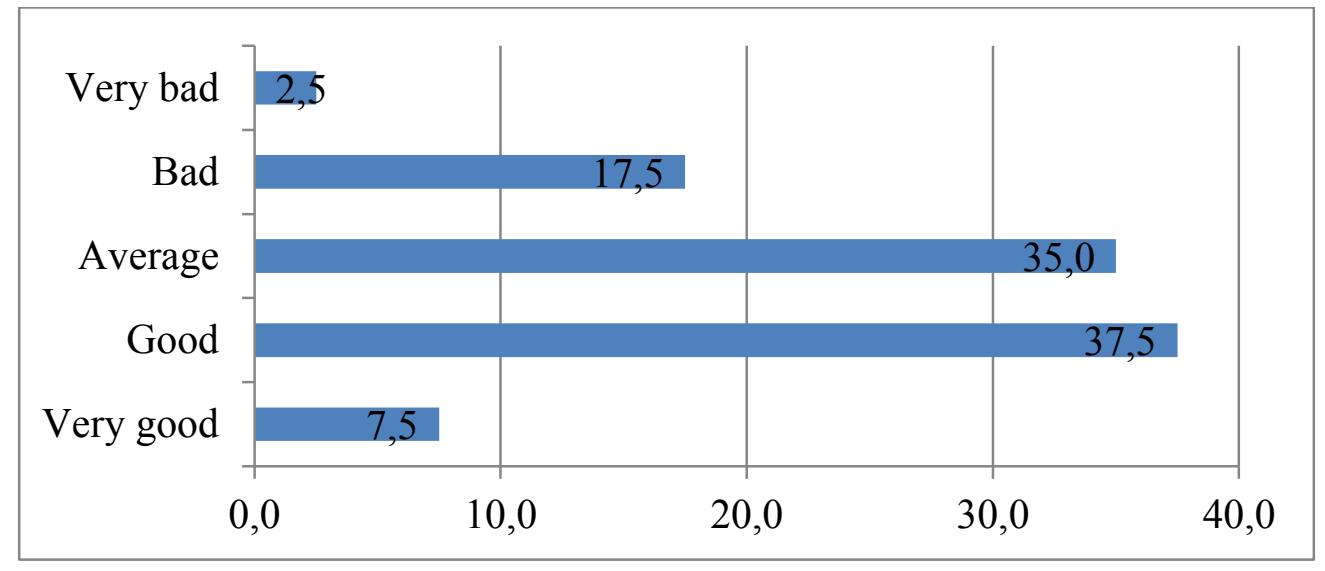

Graph 1. Health self-evaluation

T-test results in relation to gender and applied scales estimates are shown in Table 2. From the table we can conclude that male respondents, in comparison to female respondents, have better results in variables of physical and social functioning. Female respond- ents show better results in variable "Scale of feelings about life". Although means show there are differences in acquired results between the genders, t-test results have shown that those differences are not statistically significant. 
Table 2. T-test results in relation to gender and applied evaluation scales

\begin{tabular}{|c|c|c|c|c|c|c|c|}
\hline Variables & Gender & $\mathbf{N}$ & $\mathbf{M}$ & SD & $\overline{\text { SE }}$ & $\mathbf{t}$ & $\mathbf{p}$ \\
\hline \multirow[t]{2}{*}{ Physical functioning } & $\mathrm{M}$ & 13 & 9.53 & 2.40 & .66 & \multirow{2}{*}{$-1,14$} & \multirow{2}{*}{.258} \\
\hline & $\mathrm{F}$ & 27 & 10.88 & 3.88 & .74 & & \\
\hline \multirow[t]{2}{*}{ Social functioning } & $\mathrm{M}$ & 13 & 7.07 & 2.78 & .77 & \multirow{2}{*}{-.32} & \multirow{2}{*}{.748} \\
\hline & $\mathrm{F}$ & 27 & 7.33 & 2.11 & .40 & & \\
\hline \multirow{2}{*}{$\begin{array}{l}\text { Feelings about life } \\
\text { scale }\end{array}$} & $\mathrm{M}$ & 13 & 32.30 & 3.22 & .89 & \multirow{2}{*}{.51} & \multirow{2}{*}{.607} \\
\hline & $\mathrm{F}$ & 27 & 31.81 & 2.60 & .50 & & \\
\hline
\end{tabular}

Results acquired in Table 3, show that larger percentage of female respondents evaluate their health as bad and very bad, in comparison to male respondents which evaluate their health as good and very good. Results of hi-square test have shown that there is no statistically significant difference in relation to gender of respondents with health selfevaluation.

Table 3. Hi-square test results in relation to gender and health

\begin{tabular}{cccccccc}
\hline \multirow{2}{*}{ Gender } & & Very Good & Good & State of health & \multicolumn{2}{c}{ Total } \\
& & Average & Bad & Very Bad & \\
\hline Male & $\mathrm{N}$ & 2 & 7 & 3 & 1 & 0 & 13 \\
& $\%$ & 15.4 & 53.8 & 23.1 & 7.7 & 0.0 & 100.0 \\
\multirow{2}{*}{ Female } & $\mathrm{N}$ & 1 & 8 & 11 & 6 & 1 & 27 \\
& $\%$ & 3.7 & 29.6 & 40.7 & 22.2 & 3.7 & 100.0 \\
Total & $\mathrm{N}$ & 3 & 15 & 14 & 7 & 1 & 40 \\
& $\%$ & 7.5 & 37.5 & 35.0 & 17.5 & 2.5 & 100.0 \\
\hline
\end{tabular}

\section{DISCUSSION}

Personal evaluation of satisfaction with life includes subjective thinking in a way, how important certain area is for an individual and how satisfied that individual is with that area (Gojceta et al., 2008). In our research, most respondents have evaluated their health as good and average while $2.5 \%$ of respondents with subjective evaluation have estimated their health as very bad. Vuletic and Mujkic (2002a) point out that every person experiences situation they live in differently, has different aspirations and expectations - has different value system and therefore values differently quality of their own life.

Research that was conducted by Susnjevic (2015) in form of study of average on sample of respondents with motoric disabilities older than 18 years $(n=226)$, that are recorded in associations of persons with motoric invalidity, on the same measuring instrument have shown that average value in domain of physical functioning for male population is 84.2 and for female population 86.0 and that difference in relation to gender is not statistically significant $(p=0.553)$. However, results in scale of social functioning have shown that there is statistically significant difference in relation to gender $(p=0.003)$, while in domain of scale of feelings about life $(p=0.170)$ and scale of self-evaluation $(\mathrm{p}=0.802)$, differences in relation to gender are not statistically significant.

In our research, results means have shown that male respondents have shown better results in variables of physical and social functioning in comparison to female respondents. In other hand, female respondents have shown better results in feelings about life variables. However, although means show that there are differences in acquired results comparing female and male respondents, $t$-test results have shown that those differences are not statistically significant. 
Having in mind that our respondents live in institutional accommodation, results can be correlated to other influencing factors such as separation from the family, other illnesses, circumstances with visual impairment, lack of caring for their health, combination of many diseases. In general population researches, it's been proven that, larger social support is related to better dealing with every-day activities (Oxman \& Hull, 1997; Jang et al., 2003, according to Tabrett \& Latham, 2011). It's been reported that people with visual impairments, bigger support from family members is related to larger restriction in activities that involve eye-sight (Reinhard, 2001, according to Tabrett \& Latham, 2011). Therefore, although lower quality of life of these persons is attributed to visual impairment, there is a possibility that it has been influenced more by other, prior mentioned circumstances then impairment itself (Chia et al., 2004).

Research results from Li et al., (2011) that examined relation between quality of life and visual impairment have shown that persons that have more severe visual impairments have equal or better results on some subscales of quality of life then persons with milder visual impairments. As possible reason for those results, authors claim that persons with more severe visual impairments in moment of questioning have had longer time since impairment first appeared and that made it possible for them to accept it and adjust.

\section{CONCLUSION}

Quality of life researches with persons with disabilities is gaining more and more of importance in clinical and in population researches because improvements in health and quality of living is most important goal of every society. Papers on quality of life of this population category are rare event in worldly literature and are aiming to comprehend particular components of health and quality of living and not to make global assessments. Quality of living includes physical, mental and social domain of health and it is under the influence of experience, beliefs and perception. By measuring quality of life, Jakovljevic and Grujic (1995) consider that different variables should be included which will give reliable information about symptoms, functional capacity (self-care, every-day activities in and around the house, at work, in the community, hobbies, recreation...), diseases or welfare, patient's expectations, relation between expected and accomplished, emotional function, need for medical and other services, social and economic consequences of disease. Any kind of disability, therefore visual impairment, can affect person's psychological, physical and social integrity. Researching quality of life of persons with visual impairment is essential because it enables tracking adjustments to disability, functioning in new, every-day situations, mobility and orientation, depending on degree of visual impairment, as well as general welfare and satisfaction with life, but also enables tracking availability healthcare and social care and in the end respect for human rights.

\section{LITERATURE}

Bosworth, H. B., Siegler, I. C., Brummett, B. H., Barefoot, J. C., Williams, R. B., Vitaliano, P. P., Clapp-Channing, N., Lytle, B. L. i Mark, D. B. (1999). The relationship between self-rated health and health status among coronary artery patients. Journal of Aging and Health, 11 (4): 565-584.

Bowling, A. (1991).Measuring health: a review of quality of life measurement scales. Milton Keynes, Open University Press.

Chia, E.-M., Wang, J. J., Rochtchina, E., Wayne, S., Cumming R. R., Mitchell, P. (2004). Impact of bilateral visual impairment on health-related quality of life: the blue mountains eye study. Investigative ophthalmology and visual science: $45(1): 71-76$.

Ćorić, O., Ljubotina, D. (2013).Kvaliteta života ratnih veterana s tjelesnim invaliditetom koji igraju sjedeću odbojku. Ljetopis socijalnog rada, 20 (3):187-414.

Fenwick, E. K., Pesudovs, K., Ress, G., Dirani, M., Kawasaki, R., Wong, T.Y., Lamoreux, E. L. (2012). The impact of diabetic retinopathy: understending the patient's perspective. The british journal of ophthalmology, 95: 774-782.

Gojčeta, M., Joković Oreb, I., \& Pinjatela, R. (2008).Neki aspekti kvalitete života adolescenata sa i bez cerebralne paralize. Hrvatska revija za rehabilitacijska istraživanja, 44 (1): 39-4.

Idler, E. L. (1999). Self-assessments of health: the next stage of studies. Research on Aging, 21 (3): 387-391.

Jakovljević, Đ. \& Grujić V. (1995). Socijalna medicina.Medicinski fakultet Novi Sad, Univerzitet u Novom Sadu.

Li, Y., Crews, J. E., Elam-Evans, L. D., Fan, A. Z., Zhang, X., Elliott, A. F., Balluz, A. (2011). Visual impairment and health-related quality of life among elderly adults with age-related eye diseases.Quality of life research, 20: 845852.

Lorger, M. (2011). Sport i kvaliteta života mladih. Doktorska disertacija. Kineziološki fakultet Sveučilišta u Zagrebu.

Lučev, I., Tadinac, M. (2008).Kvaliteta života u Hrvatskoj povezanost subjektivnih i objektivnih indikatora temperamenta i demografskih varijabli s osvrtom na manjinski status. Migracijske i etničke teme, 24 (1-2):67-89.

Maca, M. S., Amirian, A., Prause, C., Gruber, K., Mejdoubi, L., Barisani-Asenbauer, T. (2013).Understanding the impact of uveitis on health-related quality of life in adolescents. Actaoftamologica, 91: 219-224. 
Navarro Esteban, J.J., Solera Martinez, M., Garcia Navalon,P., Pinar Serrano, O. CerrilloPatino, J.R., CallePuron, M. E., Martinez Vizcaino, V. (2008). Visual impairment and quality of life: gender differences in the elderly in Cuenca, Spain. Quality of life research, 17:37-45.

Nyman, S. R., Gosney, M. A., Victor, C. R., (2011). Psychosocial impact of visual impairment in working-age adult.The British Journal of Ophthalmology, 94: 1427- 1431.

Pinquart, M., Pfeiffer J.P. (2011).Psyhological well-being in visually impaired and unimpaired individuals: A meta-analysis. British Journal of Visually Impairment, 29(1):27-45.

Sekeroglu, H. T., Kadayifcilar, S., Eldem, B. (2012). Quality of life in the elderly population: effects of age related macular degeneration on NEI-VFQ 25 scores. Turkish Journal of Geriatrics, 15(2):134-141.

Šušnjević, S. (2015). Kvalitet života odraslih osoba sa motornim invaliditetom na teritoriji Vojvodine. Doktorskadisertacija. Medicinski fakultet Novi Sad, Univerzitet u Novom Sadu.

Tabrett, D. R., Latham, K. (2011). Factor infuencing self-reported vision-related activity limitation in the visualy impaired. Investigative ophthamology and visual science, 52(8): 5293-5302.
Tsai, S-Y., Chi, L.-Y., Cheng, C.-Y., Hsu, W.-M., Liu, J.-H., Chou, P. (2004). The impact of visual impairment and use of eye services on health-related quality of life among the elderly in Taiwan: The Shihpai Eye Study. Quality of life research, 13: 1415-1424.

Vuletić, G., Mujkić, A. (2002a). Što čini osobnu kvalitetu života, Studija na uzorku Hrvatske gradske populacije. Liječnički vijesnik, 12(2):64-70.

Vuletić, G., Mujkić, A. (2002b). Što čini osobnu kvalitetu života: Studija na uzorku Hrvatske gradske populacije. Škola na rodnog zdravlja "A. Štampar" Medicinski fakultet Sveučilišta u Zagrebu, 1-17.

West, S.K., Munoz, B., Rubin, G.S., Shein, O. D., Bandeen-Roche, K., Zeger, S., German, P. S., Fried, L. P. (1997). Function and visual impairment in a populationbased study of older adults. Investigative ophthalmology \& visual science, 38(1):72- 82 . 